OECDpublishing

DOES FISCAL

DECENTRALISATION

FOSTER REGIONAL

CONVERGENCE?

OECD ECONOMIC POLICY PAPER

September 2016 No. 17 


\section{Does Fiscal Decentralisation Foster Regional Convergence?}

This paper has been prepared by:

Hansjörg Blöchliger

David Bartolini

Sibylle Stossberg 
The OECD Economic Policy Paper Series is published on the responsibility of the Secretary-General of the OECD. The opinions expressed and arguments employed herein do not necessarily reflect the official views of the Organisation or of the governments of its member countries.

Hansjörg Blöchliger and David Bartolini are in the Economics Department and the Public Governance and Territorial Development Directorate of the OECD and Sibylle Stossberg is with the German Federal Ministry of Finance (Bundesministerium der Finanzen). At the time of writing this paper, David Bartolini was with the Economics Department and Sibylle Stossberg was on leave from the Ministry.

An earlier version of this paper was discussed at the meeting of the OECD Network on Fiscal Relations across Levels of Government. The authors would like to thank the participants as well as Monica Brezzi, Jose Enrique Garcilazo, Luiz de Mello and Joaquim Oliveira-Martins (Public Governance and Territorial Development Directorate), Peter Hoeller, Christian Kastrop, Jean-Luc Schneider and Eckhard Wurzel (Economics Department) for their comments and suggestions. They thank Celia Rutkoski for excellent editorial assistance.

More detailed information is contained in the following papers:

Arnold, F. and H. Blöchliger (2016), "Regional GDP in OECD Countries: How Has Inequality Developed over Time?", OECD Economics Department Working Paper, No. 1329, OECD Publishing.

Bartolini, D., S. Stossberg and H. Blöchliger (2016), "Fiscal Decentralisation and Regional Disparities", OECD Economics Department Working Paper, No. 1330, OECD Publishing.

Stossberg, S., D. Bartolini and H. Blöchliger (2016), "Fiscal Decentralisation and Income Inequality: Empirical Evidence from OECD Countries", OECD Economics Department Working Paper, No. 1331, OECD Publishing.

\section{Series: OECD Economic Policy Papers} ISSN $2226583 X$

Latvia was not an OECD Member at the time of preparation of this publication. Accordingly, Latvia does not appear in the list of OECD Members and is not included in the zone aggregates.

This document and any map included herein are without prejudice to the status of or sovereignty over any territory, to the delimitation of international frontiers and boundaries and to the name of any territory, city or area.

The statistical data for Israel are supplied by and under the responsibility of the relevant Israeli authorities. The use of such data by the OECD is without prejudice to the status of the Golan Heights, East Jerusalem and Israeli settlements in the West Bank under the terms of international law.

\section{(C) OECD 2016}

You can copy, download or print OECD content for your own use, and you can include excerpts from OECD publications, databases and multimedia products in your own documents, presentations, blogs, websites and teaching materials, provided that suitable acknowledgment of OECD as source and copyright owner is given. All requests for public or commercial use and translation rights should be submitted to rights@oecd.org. Requests for permission to photocopy portions of this material for public or commercial use shall be addressed directly to the Copyright Clearance Center (CCC) at info@copyright.com or the Centre français d'exploitation du droit de copie (CFC) at contact@cfcopies.com. 


\section{TABLE OF CONTENTS}

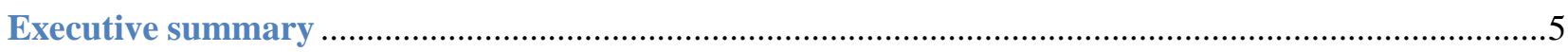

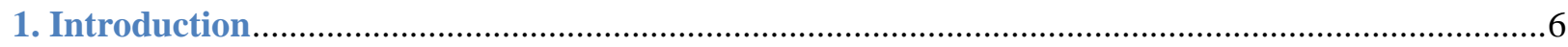

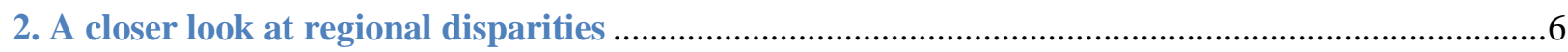

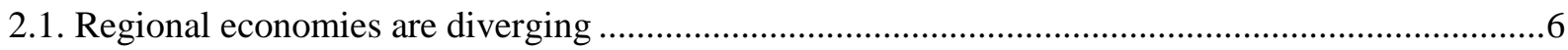

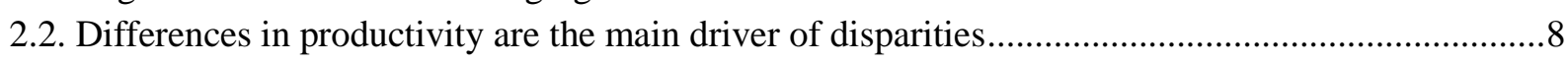

2.3. OECD countries are on the downward-sloping side of the Kuznets curve .......................................9

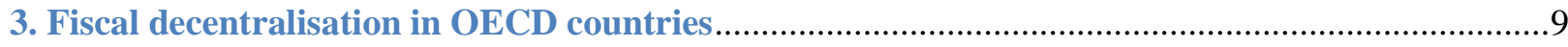

4. Does decentralisation fuel or dampen regional disparities? .........................................................10

4.1. Transmission from decentralisation to disparities........................................................................10

4.2. Regional disparities and fiscal decentralisation: Evidence from OECD countries .........................11

4.3. Poorer regions benefit more from decentralisation than richer ones.............................................13

4.4. What explains the disparity-reducing effect of decentralisation? ................................................14

4.5. Trade-offs between regional activity and regional income could become apparent ......................15

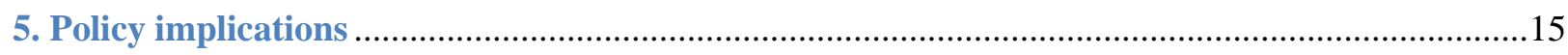

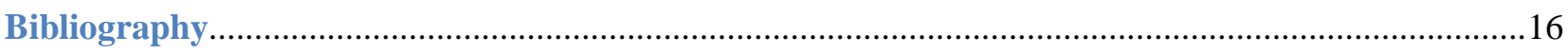

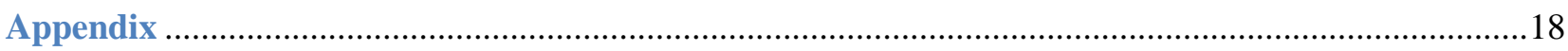

Table

1. Revenue decentralisation benefits all regions................................................................................14

\section{Figures}

1. Inequality is decreasing between but increasing within countries...................................................

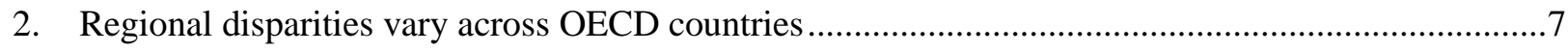

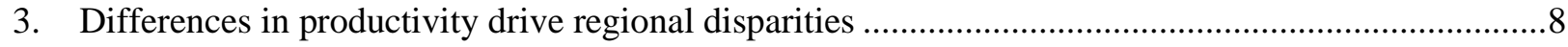

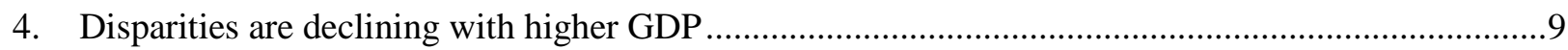

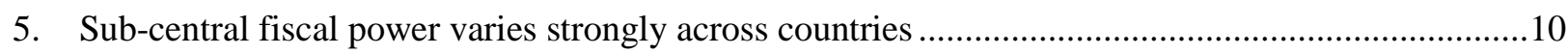

6. Channels from decentralisation to regional disparities ............................................................11

7. Tax autonomy and balanced decentralisation tend to be associated with lower disparities ...............12

8. Revenue decentralisation tend to reduce disparities, while intergovernmental grants raise them......13 


\section{Abstract \\ Does Fiscal Decentralisation Foster Regional Convergence?}

Across the OECD, GDP per capita is converging. In contrast, regional disparities - or differences in GDP per capita across jurisdictions - are rising, mainly as a result of widening productivity differences. Fiscal decentralisation could help reduce them again. According to new OECD research, assigning more ownsource revenue to sub-national governments dampens regional GDP disparities and underpins regional convergence. In more decentralised settings, catching-up regions appear to adopt policy innovations more rapidly and their policy innovations have a stronger impact. Conversely, intergovernmental grants tend to fuel disparities, probably because they discourage lagging regions to develop their economic and fiscal base. However, when replacing intergovernmental transfers by own-source revenue, lower disparities in regional output may come at the cost of larger disparities in regional income and more unequal public service standards. Reforms to intergovernmental fiscal frameworks should therefore be two-pronged: a rise in sub-national own-source revenue should be paired with a re-design of intergovernmental transfers and fiscal equalisation, in order to make all jurisdictions enjoy the benefits of more sub-central fiscal power.

JEL codes: D63; H10; H70; H71; H75; H77; I38

Keywords: Fiscal decentralisation, intergovernmental relations, regional disparities, intergovernmental transfers, fiscal equalisation, fiscal autonomy

\section{Résumé}

\section{La décentralisation budgétaire encourage-t-elle la convergence régionale du PIB ?}

Si l'on observe une convergence des PIB par habitant au sein de la zone OCDE, en revanche, les disparités régionales, c'est-à-dire, les écarts de PIB par habitant entre régions d'un même pays, se creusent, essentiellement du fait de l'augmentation des écarts de productivité. La décentralisation budgétaire pourrait contribuer à ce que ces disparités se réduisent de nouveau. Une nouvelle étude de l'OCDE montre que les disparités régionales de PIB sont atténuées et la convergence entre les régions stimulée lorsque les administrations infranationales disposent de recettes propres plus importantes. Il semble que, dans un environnement plus décentralisé, les régions en phase de rattrapage adoptent plus rapidement les innovations de politique publique et que celles-ci aient un impact plus fort. À l'inverse, les transferts interadministrations tendent à alimenter les disparités, probablement parce qu'ils n'incitent pas les régions en retard à élargir leur assise économique et budgétaire. Toutefois, en remplaçant les transferts interadministrations par des recettes propres, on risque de voir la réduction des différences régionales au niveau de la production s'opérer au prix d'un creusement des disparités au niveau des revenus et d'un accroissement des inégalités en matière de normes de service public. Les réformes des cadres budgétaires interadministrations devraient donc être déployées en deux volets: l'augmentation des recettes infranationales propres devrait être couplée à une redéfinition des transferts interadministrations et de la péréquation budgétaire, de façon que toutes les juridictions profitent des avantages du renforcement du pouvoir budgétaire des administrations infranationales.

Classification JEL : D63 ; H10 ; H70 ; H71 ; H75 ; H77 ; I38

Mots-clés : décentralisation budgétaire ; relations interadministrations ; disparités régionales ; transferts interadministrations ; péréquation budgétaire ; autonomie budgétaire 


\section{Does Fiscal Decentralisation Foster Regional Convergence?}

\section{Executive summary}

1. Disparities in regional GDP per capita levels have risen in most OECD countries. This has fuelled debates about potential trade-offs between growth and regional inequality especially in countries that contemplate fiscal federalism reforms. While some point at the growth-enhancing effects of fiscal decentralisation and argue that the efficiency-enhancing effects lift all boats, others point out that decentralisation would widen differences in regional competitiveness and argue that some places would be left behind.

2. This paper sheds light on the relationship between fiscal decentralisation and differences in economic activity across regions. It also provides some policy guidance on how to redesign intergovernmental fiscal frameworks to foster regional convergence. It complements the earlier work of the Fiscal Network on "decentralisation and growth" (Blöchliger et al., 2013), thereby focussing on how the growth dividend of fiscal decentralisation could be better distributed.

3. The main findings are as follows:

- $\quad$ Over the last two decades or so, differences in regional GDP per capita increased in most OECD countries. Rising productivity differences are the main driver of diverging economic activity across jurisdictions.

- $\quad$ Fiscal decentralisation - in particular revenue decentralisation - tends to reduce disparities in regional GDP per capita. In particular, own-source revenue could spur growth in poorer regions and underpin the catch-up process towards the frontier regions.

- Intergovernmental transfers, covering the difference between sub-national own-source revenue and spending, tend to increase disparities in regional GDP per capita.

- Fiscal autonomy helps the catching-up regions more than those above the national average. Catching-up regions appear to adopt policy innovations more rapidly and their policy innovations have a stronger impact on economic activity.

4. Overall, stronger fiscal decentralisation can underpin regional convergence. However, there are trade-offs, and policies aimed at strengthening sub-national fiscal power should take them on board. Balanced decentralisation, where sub-central spending is largely covered by own revenues rather than intergovernmental transfers, tends to spur long-term regional convergence in economic activity. Yet transfers often help equalise regional income and contribute to achieving common public service standards across a country. If more fiscal power is to be devolved to lower government levels, transfers systems and fiscal equalisation have to be carefully redesigned. 


\section{Introduction}

5. Rising disparities in regional GDP per capita have fuelled debates about potential trade-offs between growth and inequality. Views on the links between intergovernmental fiscal frameworks and regional disparities vary widely. While some point at the growth-enhancing effects of fiscal decentralisation and argue that the efficiency-enhancing effects lift all boats, others point out that decentralisation would widen differences in regional competitiveness and argue that some places would be left behind. The role of government in more decentralised settings is also debated. Decentralisation sceptics argue that only the central government can redistribute effectively across regions and hence that further decentralisation would curtail this role. Proponents of more decentralisation counter that decentralisation fosters economic development in all regions and that regional redistribution slows down rather than underpins convergence.

6. This paper sheds light on the relationship between intergovernmental fiscal frameworks and differences in economic activity across sub-central jurisdictions. The paper is organised as follows: The second section presents stylised facts about the level and evolution of regional per capita GDP and productivity disparities across countries. The third section gives a short overview on fiscal decentralisation in the OECD. The fourth section surveys the various channels from decentralisation to regional output disparities and then examines the relationship between disparities and various decentralisation indicators, including the role of intergovernmental grants for regional convergence. The fifth section provides policy conclusions. Detailed results are available in Bartolini et al. (2016).

\section{A closer look at regional disparities}

\subsection{Regional economies are diverging}

7. Regional disparities have risen slowly over the past 15 years. Across the OECD the differences in sub-central GDP per capita, as measured by the coefficient of variation, rose from 0.26 to 0.28 on average between 1995 and 2013 (Figure 1). ${ }^{1}$ Most strikingly, rising disparities within OECD countries were accompanied by an even more pronounced decline in disparities between these countries. Put in other words, countries are converging, while regions are diverging. Only recently have inter-regional disparities begun to shrink again. Regional disparities have risen in both the European Union and the United States (Montfort, 2009; Young et al., 2008). Between 1995 and 2013, differences increased in 15 of the OECD countries included in our sample, while they declined only in eight and remained unchanged in two countries (Figure 2).

1. The term "region" refers to the Territorial Level 2 (TL2 or "large regions") in the classification of the OECD territorial statistics. This level usually corresponds to the highest tier of sub-central governments (states, Länder, regions, provinces etc.). However, the TL2 level does not always comply with political or administrative jurisdictions. 
Figure 1. Inequality is decreasing between but increasing within countries

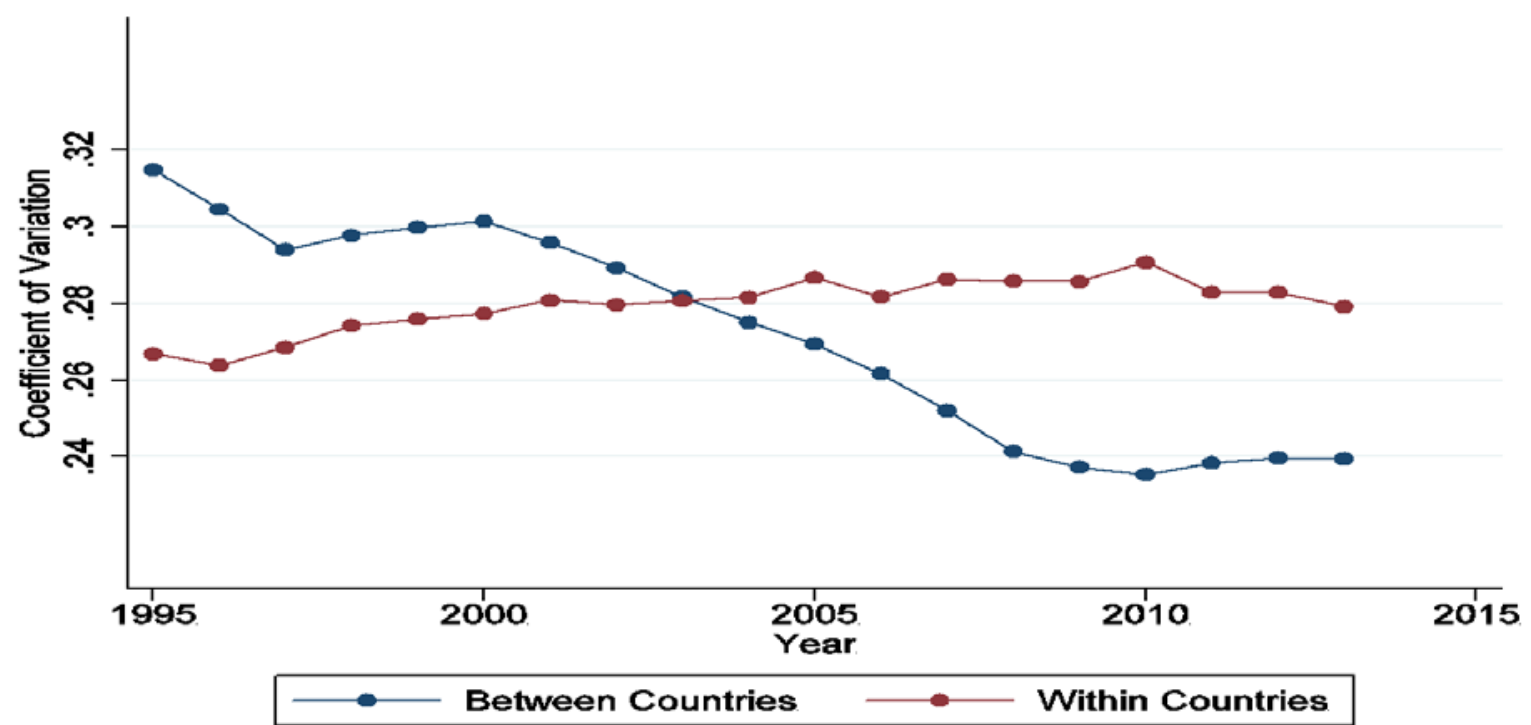

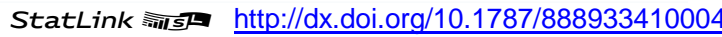

Note: The indicator OECD within is the coefficient of variation of regional GDP per capita within each country, averaged over the OECD countries available in our sample; the indicator OECD between is the coefficient of variation of national GDP per capita between those countries. The coefficient of variation is a measure for disparities in GDP per capita. The sample includes 26 OECD countries; among the current member countries the following are excluded: Luxembourg and Estonia because of the presence of only one TL2 region; Iceland, Israel, Mexico, Norway, Switzerland and Turkey for lack of regional data for the whole period considered.

Source: Calculations based on data from OECD (2015), National Accounts at a Glance 2015, OECD Publishing, Paris and OECD (2016), "Regional economy", OECD Regional Statistics (database).

Figure 2. Regional disparities vary across OECD countries Coefficient of variation of regional GDP per capita at territorial level 2, 1995 and 2013

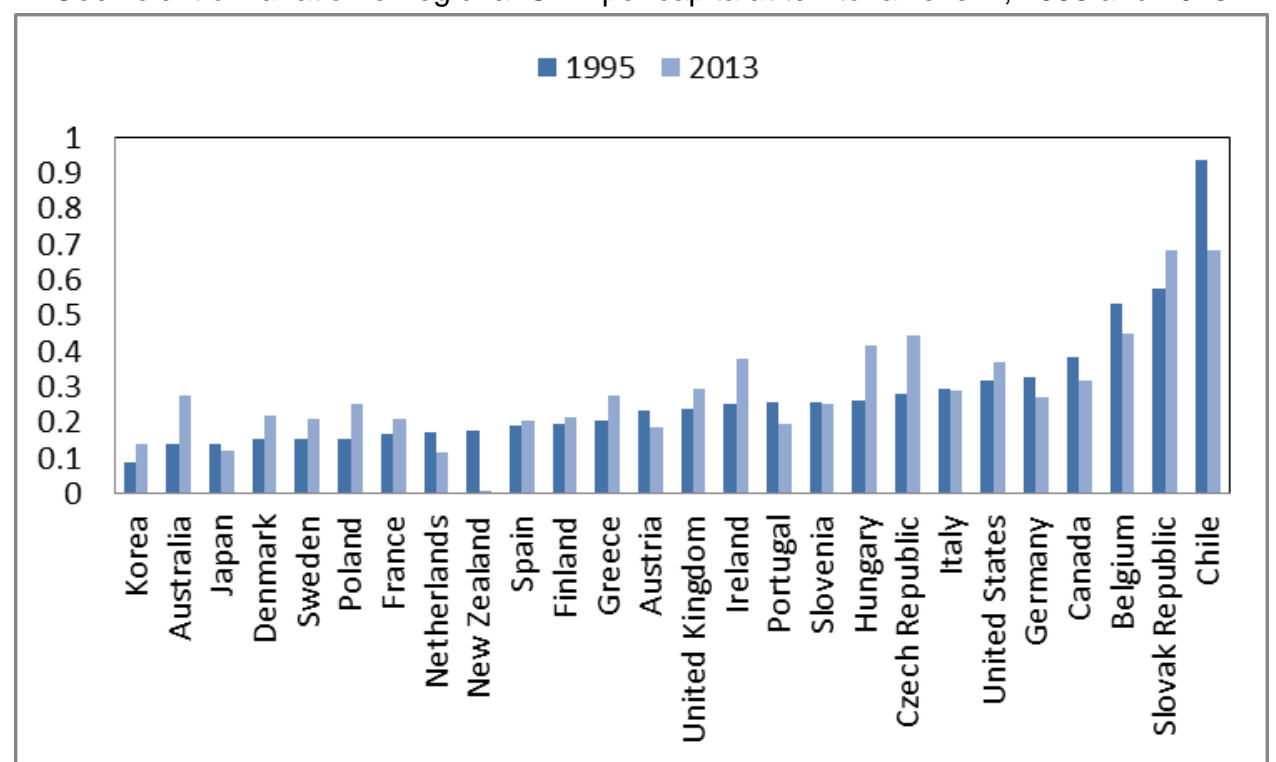

StatLink - जाIs http://dx.doi.org/10.1787/888933410015

Note: The sample includes only the OECD member countries for which regional data are available for the year 1995 and the year 2013.

Source: OECD (2016), "Regional economy", OECD Regional Statistics (database). 
8. The rise in regional disparities is sometimes seen as the result of two interconnected trends, namely globalisation and localisation or agglomeration economies (McCann, 2008):

- Globalisation: Globalisation benefits regions unequally. In general, trade and other forms of international exchange are dominated by networks of firms in large agglomerations. As such, convergence of countries is driven by convergence of regions that are well-integrated into global value chains. Trickle-down effects from regions at the productivity frontier towards less productive jurisdictions could have slowed down, similar to the trickle-down from firms at the productivity frontier towards the non-frontier firms which also appears to have slowed down (OECD, 2015b).

- Agglomeration economies: Knowledge spill-overs and productivity externalities are often geographically bound and cannot be replicated outside agglomerations. As a result, productivity tends to be higher in large conurbations. The growth of agglomerations can be self-propelling: people and firms attracted by high productivity and wage premia in an agglomeration may increase rather than decrease existing productivity gaps, fuelling differences in regional output further. Such "endogenous regional growth" can reverse regional convergence and exacerbate regional disparities (Roberts and Setterfield, 2007).

9. The two trends have triggered lively and yet unsettled policy debates on the relevance of these two forces for regional development and for the role of regional policy in providing targeted support to certain jurisdictions.

\subsection{Differences in productivity are the main driver of disparities}

10. Decomposing GDP per capita into GDP per worker, which is a proxy for productivity, the employment rate and the activity rate reveals that the main driver of differences in regional GDP per capita is differences in productivity (Figure 3). Employment and activity rates are much more evenly distributed, suggesting that productivity is the main determinant in the evolution of and differences in GDP per capita (OECD, 2015). Exceptions to this pattern are Italy and Spain, where employment differs widely across regions, and Japan, where the active population is concentrated in few jurisdictions.

Figure 3. Differences in productivity drive regional disparities Decomposition of disparities in regional GDP

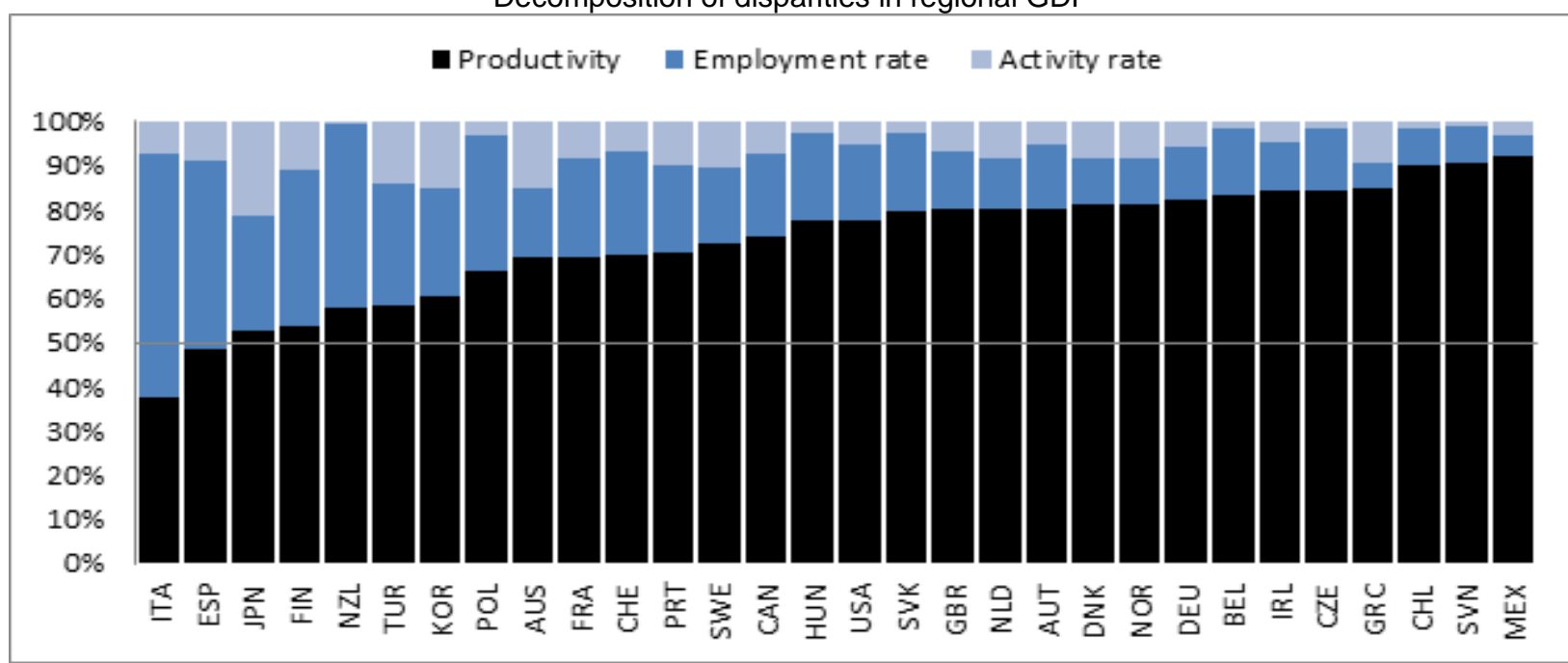

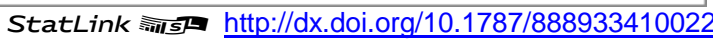

Note: Disparities in regional GDP per capita are decomposed into the contributions of labour productivity (GDP per worker), labour resource utilisation (those employed as a share of the active working population) and the activity rate (per cent of the active working population in total population).

Source: OECD (2016), "Regional economy", OECD Regional Statistics (database). 


\subsection{OECD countries are on the downward-sloping side of the Kuznets curve}

11. Kuznets' (1955) hypothesis posits an inverted U-relationship between income inequality and percapita income. Inequality widens during the early phase of economic development, then stabilises and eventually declines at a high stage of economic development. Williamson (1965) applied this idea to the relationship between disparities in regional GDP and national GDP levels. Plotting this relationship with data from OECD countries reveals that they are located on the downward-sloping side of that curve (Figure 4). Richer OECD countries feature lower regional disparities than poorer ones, although at some income level the curve tends to level out or even rises again. Given this relationship, regional disparities should actually have declined rather than grown in the past. Maybe the fiscal and institutional framework plays a pivotal role for the path of inter-jurisdictional differences in a country. This is the topic of the following sections.

Figure 4. Disparities are declining with higher GDP

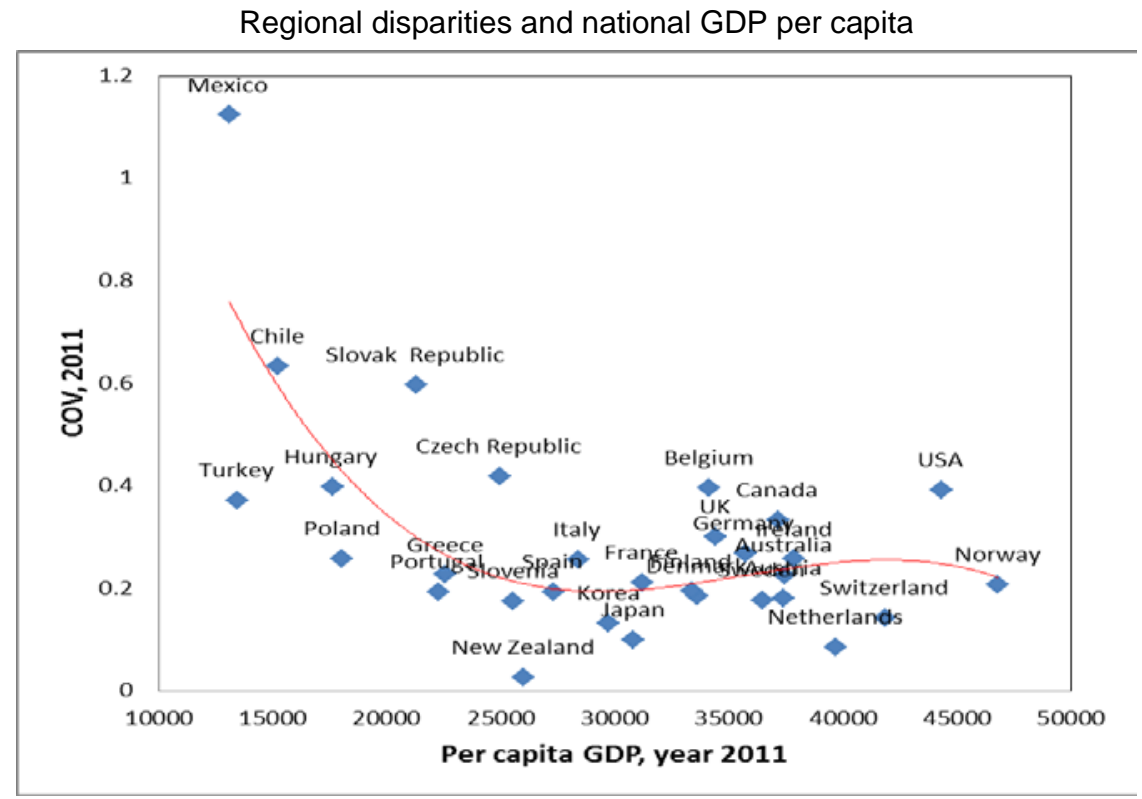

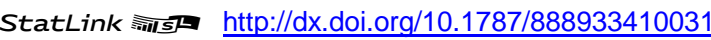

Note: GDP per capita is expressed in constant PPP USD (2005). COV is the coefficient of variation of regional GDP per capita in each country.

Source: OECD (2016), "Regional economy", OECD Regional Statistics (database).

\section{Fiscal decentralisation in OECD countries}

12. The extent of fiscal decentralisation varies strongly across countries but has changed little over time, although several countries devolved far-reaching fiscal powers to sub-central governments over the last two decades. Spending is far more decentralised than taxation, with sub-central governments often largely financed through transfers rather than own revenue (Figure 5). Spending decentralisation rose slowly from the mid-1990s until around 2005 when sub-central spending reached about $35 \%$ of total government spending, reflecting a wave of devolution of core functions in education, health care and economic affairs. After the mid-2000s, the spending share started to decline, partly reflecting a reining in of sub-central spending excesses, partly a few recentralisation measures and, after 2008, the role of central government stimulus programmes (OECD, 2014a). The share of sub-central in total government revenue changed less, hovering at around $20 \%$ over that period. The vertical fiscal imbalance - the difference between spending and revenue decentralisation - increased slightly. 
Figure 5. Sub-central fiscal power varies strongly across countries

Panel A: Decentralisation ratios, 2014

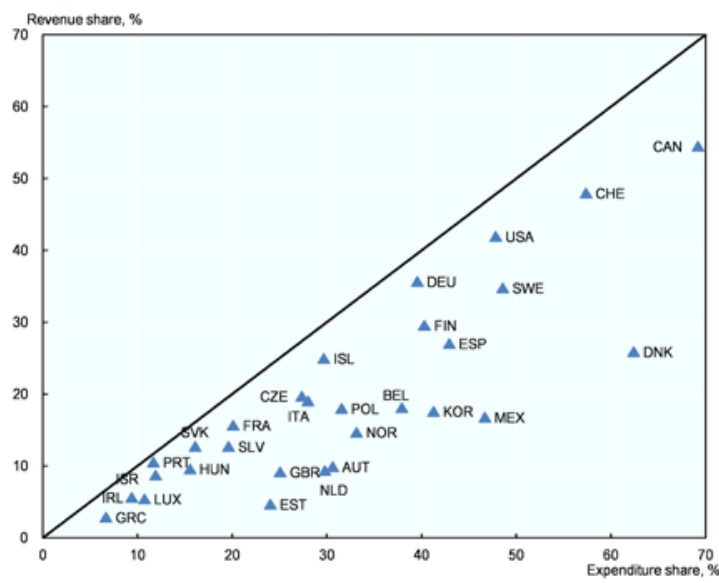

Panel B: Evolution 1995-2014

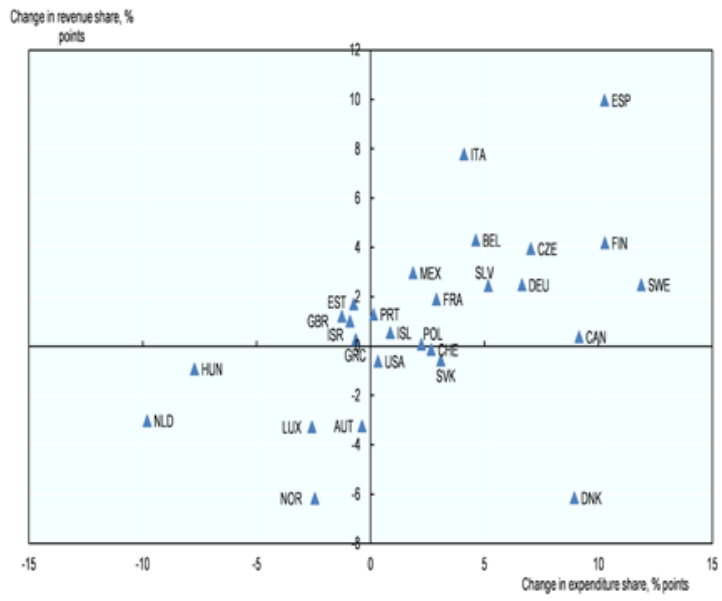

StatLink 제내 http://dx.doi.org/10.1787/888933410049

Note: Panel A: the 45 degree line reflects a situation where the sub-central spending and revenue shares are identical. Revenues exclude intergovernmental transfers. Panel B: Greece: 2006-14; Iceland: 1998-2014; Mexico: 2003-13; Poland: 2005-14. Ireland was excluded due to a change in the national accounts.

Source: OECD Fiscal Decentralisation Database, www.oecd.org/tax/federalism/oecdfiscaldecentralisationdatabase.htm.

13. Intergovernmental fiscal frameworks are complex and must hence be assessed comprehensively. Many empirical studies apply several indicators in parallel when addressing the link between decentralisation and regional disparities, such as sub-national government spending, revenue or tax revenue shares. Moreover, institutional indicators such as tax autonomy or fiscal authority often complement the traditional ratios, in order to reflect the complex nature of sub-national government power. A key variable is the vertical fiscal balance - the difference between sub-central own spending and own tax revenue - and the set of intergovernmental transfers that cover it. As will be shown, transfers have widereaching implications for regional GDP levels and growth rates.

\section{Does decentralisation fuel or dampen regional disparities?}

14. The following sections first give a brief overview on the transmission channels by which intergovernmental fiscal frameworks can affect disparities in economic activity as measured by regional GDP per capita. Then they present the results of an empirical study linking differences in activity to intergovernmental fiscal frameworks and other determinants.

\subsection{Transmission from decentralisation to disparities}

15. Intergovernmental fiscal frameworks are supposed to affect regional economic activity, productivity or household income through two main channels: (1) an "accountability" channel which pertains to how different government levels react to the needs and preferences of voters, and (2) a "growth" channel which pertains to how intergovernmental frameworks affect public and private investment, productivity and employment (Figure 6). 
Figure 6. Channels from decentralisation to regional disparities

A simplified view on the drivers of differences in regional economic activity

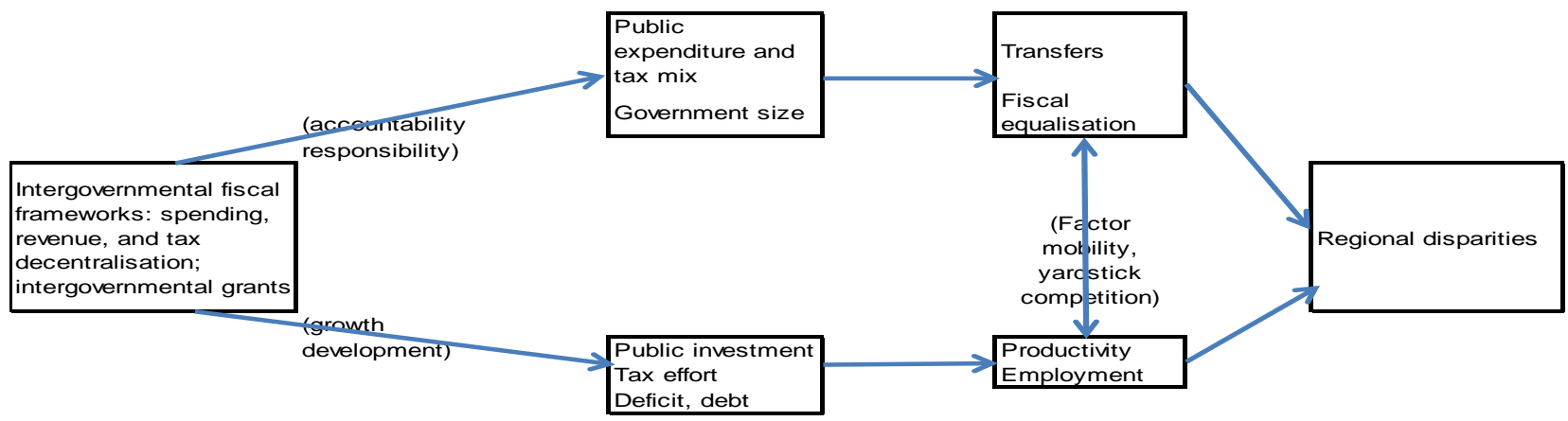

Source: OECD Secretariat, based on Blöchliger, H. and B. Égert (2013), "Decentralisation and Economic Growth - Part 2: The Impact on Economic Activity, Productivity and Investment"; OECD Working Papers on Fiscal Federalism, No. 15, OECD Publishing; Sepulveda and Martinez-Vazquez (2011), "The Consequences of Fiscal Decentralization on Poverty and Income Equality", Environment and Planning C: Government and Policy, Vol. 29, pp. 321-343.

16. The views on the effect of decentralisation on regional disparities are conflicting. Some argue that fiscal decentralisation fosters growth-oriented policies at the sub-central level, and it does so more for catching-up regions. Others argue that certain regions lack the capacity to catch up with the national average on their own. Empirical studies about whether decentralisation lifts all boats or just helps the fittest to flourish are scarce and inconclusive, though the more recent literature gives more credit to the balanced growth view. Decentralisation has been found to reduce disparities in a sample of European Union (Ezcurra and Pascual, 2008) and OECD countries (Gil et al., 2004; Kessler and Lessmann, 2010). In more heterogeneous samples, fiscal decentralisation is found to increase regional disparities in poorer countries, while it is either neutral or tends to reduce disparities in richer countries (Rodríguez-Pose and Ezcurra, 2010; Lessmann, 2012). Institutional quality seems to explain part of the story: decentralisation seems to foster convergence when institutional quality is high, which is the case in most of the richer countries, while it tends to exacerbate disparities in a low-quality environment, fuelling local capture (Kyriacou et al., 2015). Finally, the decentralisation effect is positive only when government is large (Goerl and Seyferling, 2014). For a review of the literature see Bartolini et al. (2016).

\subsection{Regional disparities and fiscal decentralisation: Evidence from OECD countries}

17. In order to assess the impact of decentralisation on regional convergence, the OECD conducted an empirical study, testing to what extent decentralisation can help reduce regional differences in economic activity (Bartolini et al., 2016). The main indicator for measuring regional disparities is the coefficient of variation of regional GDP per capita, whose decline over time is referred to as sigma-convergence (see appendix). The main findings of bivariate correlations are as follows: 1 ) the decentralisation of own-source revenue and taxing power to sub-national governments is associated with convergence of regional GDP per capita in a country, and 2) the vertical fiscal imbalance - the difference between a sub-national government's own revenue and its spending, generally covered by intergovernmental transfers - is detrimental to regional convergence (Figure 7). Dividing the sample into various sub-periods, such as between 1995-2004 and 2005-12 or distinguishing between the pre- and the post-crisis periods delivers similar results. 
Figure 7. Tax autonomy and balanced decentralisation tend to be associated with lower disparities

A) Tax autonomy and regional GDP disparities

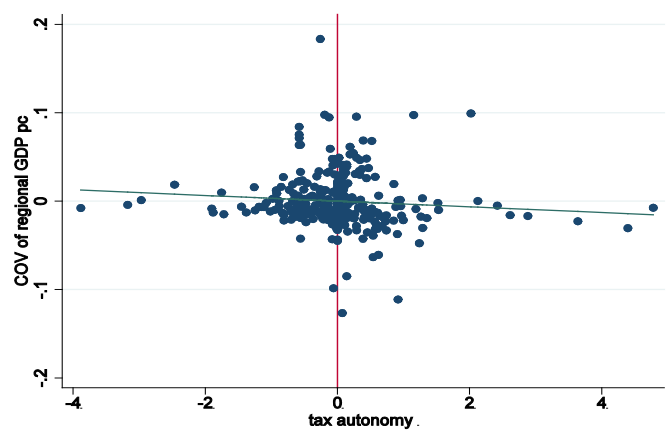

B) Vertical fiscal imbalance and regional GDP disparities

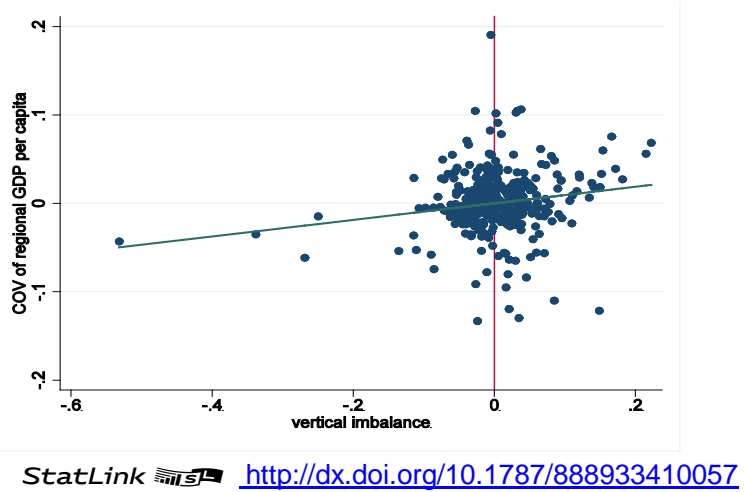

Note: The sample covers 20 OECD countries (19 for tax autonomy) and the years 1995 to 2011 . Each point reflects the coefficient of variation of regional GDP per capita in one country in one year. The lines indicate the results of a bivariate OLS regression. Variables are normalised using the respective country means to net out differences between countries that are persistent over time.

Source: OECD (2016), "Regional economy", OECD Regional Statistics (database); OECD Fiscal Decentralisation Database, www.oecd.org/tax/federalism/oecdfiscaldecentralisationdatabase.htm; OECD Secretariat calculations.

18. The multivariate econometric analysis largely confirms the results of the bivariate relationship. An increase in the sub-central own revenue share by 10 percentage points is associated with a reduction of the regional GDP coefficient of variation between 3.6 and 4.3 percentage points or around twice the amount regional disparities have risen over the last 15 years (Figure 8). Increasing the tax share by 10 percentage points reduces disparities by 2.4 to 2.8 percentage points. Devolving tax autonomy also reduces disparities although in economic terms the effect is small. On the other hand, deepening the vertical fiscal imbalance by 10 percentage points increases disparities by 1.3 to 2.8 percentage points. Spending decentralisation is associated with larger regional disparities, yet this result is largely driven by intergovernmental transfers.

19. Causality tests suggest that it is the intergovernmental fiscal framework that affects regional convergence rather than the other way round, and robustness tests suggest that no single country or a group of countries is driving the results. Overall, a balanced intergovernmental fiscal framework where subcentral spending is covered by own-source revenue seems to be more conducive to regional convergence than a framework where sub-central spending is covered by transfers. 
Figure 8. Revenue decentralisation tends to reduce disparities, while intergovernmental grants raise them Range of coefficients for each decentralisation variable

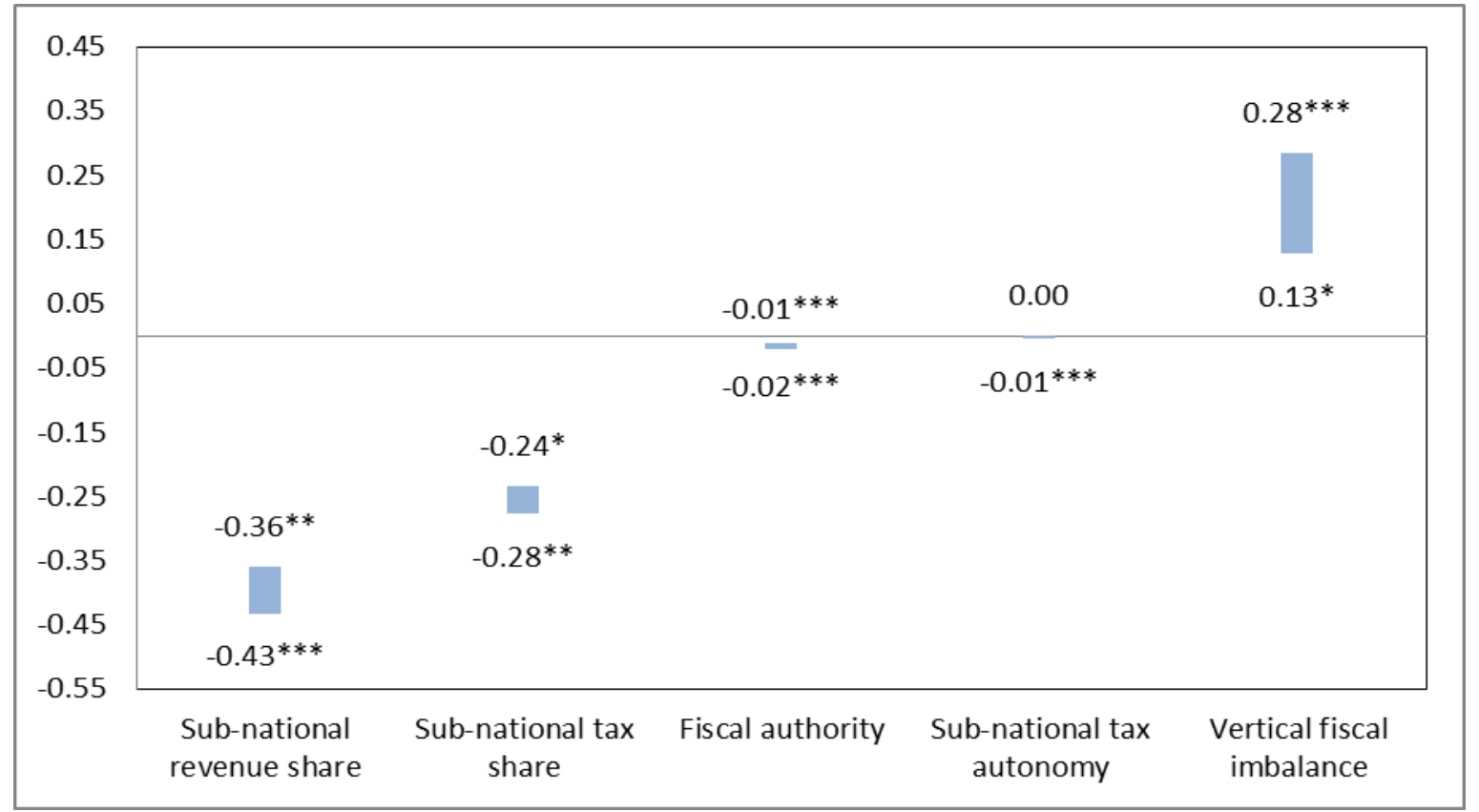

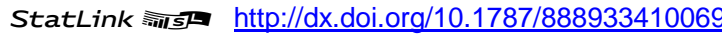

Note: The figure shows the range of estimated coefficients derived from a set of multi-variate regressions linking the coefficient of variation of regional GDP per capita in a country to the decentralisation indicators and a set of control variables. Coefficients are partial elasticities and represent percentage point changes, e.g. -0.36 means that a 10 percentage point increase in decentralisation (e.g. a revenue share increase from $12 \%$ to $22 \%$ ) is associated with a reduction in the coefficient of variation by 3.6 percentage points. A * means significance at the $10 \%$ level, $* *$ at the $5 \%$ level and $* \star *$ at the $1 \%$ level. The full set of equations including robustness checks are reported in Bartolini et al. (2016).

Source: OECD (2016), "Regional economy", OECD Regional Statistics (database); OECD Fiscal Decentralisation Database, www.oecd.org/tax/federalism/oecdfiscaldecentralisationdatabase.htm..

\subsection{Poorer regions benefit more from decentralisation than richer ones}

20. Changes in the coefficient of variation are a relatively coarse indicator for assessing regional convergence. These changes say little on convergence dynamics, especially on the extent to which subgroups of regions may deviate from the general convergence pattern. In order to have a more fine-grained picture of the role of sub-national fiscal autonomy for regional convergence, additional percentile analyses as well as tests for Beta-convergence were conducted.

21. Results of the additional analysis suggest that the disparity-reducing effect of revenue decentralisation stretches over the entire distribution of regional GDP per capita. The farther away regions are from the median, the faster they tend to draw nearer to it, as shown by the (mostly) larger and more significant coefficients for the 90/10 than the 75/25 percentile ratio (Table 1). Additional regressions linking levels and growth rates of individual jurisdictions - i.e. testing for Beta-convergence - suggest that a reduction in disparities following a decentralisation reform are driven by the catching-up regions and less so by regions closer to the frontier. These findings are salient in a political economy perspective since the tails of the distribution, i.e. the richest and poorest regions, are often more conspicuous than jurisdictions closer to the national average. 
Table 1. Revenue decentralisation benefits all regions

Top-to-bottom percentile ratios: $75 / 25$ and 90/10

\begin{tabular}{lcc}
\hline & Ratio 75/25 & Ratio 90/10 \\
\hline Tax share & -0.14 & -0.96 \\
& $(0.37)$ & $(0.68)$ \\
Expenditure share & 0.06 & 0.36 \\
& $(0.16)$ & $(0.24)$ \\
Revenue share & $-\mathbf{0 . 7 2 *}$ & $-\mathbf{1 . 6 6 ^ { * }}$ \\
& $(0.408)$ & $(0.94)$ \\
Vertical fiscal imbalance & $\mathbf{0 . 2 4 ^ { * }}$ & 0.45 \\
& $(0.12)$ & $(0.28)$ \\
Fiscal authority & -0.02 & $-\mathbf{0 . 0 4}$ \\
& $(0.01)$ & $(0.02)$ \\
Tax autonomy & -0.00 & $-\mathbf{0 . 0 2}$ \\
& $(0.01)$ & $(0.008)$ \\
Property tax (share in GDP) & -0.02 & $-\mathbf{0 . 0 6}$ \\
& $(0.02)$ & $(0.03)$ \\
Income tax (local share) & 0.12 & 0.05 \\
& $(0.24)$ & $(0.45)$ \\
\hline
\end{tabular}

Note: Coefficients are derived from multivariate regressions linking the decile ratios of regional GDP per capita in a country to the decentralisation indicators and a set of control variables. For further details see the note to Figure 8.

22. The disparity-reducing effect of decentralisation relies on a few other factors. Higher GDP per capita is associated with lower disparities, as suggested by the (truncated) Kuznets curve. Trade openness appears to exacerbate disparities, as expected, although the effect is insignificant in most regressions. Population concentration at the national level appears to be disparity-reducing, probably as a result of a population decline in thinly-populated regions and migration towards agglomerations. A larger sub-central share of welfare spending exacerbates disparities, maybe because of a vicious circle whereby poorer regions, which are responsible for social welfare, lag ever further behind. A larger government sector is associated with larger disparities, maybe because intergovernmental transfer systems, which tend to exacerbate disparities, are larger when government is large.

\subsection{What explains the disparity-reducing effect of decentralisation?}

23. In order to understand why decentralisation could reduce regional disparities, it is useful to recall that jurisdictions tend to compete for mobile households and firms. Firms' investment decisions are affected by the productivity of the public sector, and differences in service provision may induce them to change their location and/or to adapt investment. Similarly, households are affected by differences in both service levels and taxation across jurisdictions, and they may either vote or migrate if they are dissatisfied with the local or regional public sector. Inter-jurisdictional competition is therefore a core driver for growth-oriented policy reform at the regional level (Zodrow and Mieszkowski, 1986). Reliance on own revenue provides jurisdictions with both the incentives and the capacity to adopt policies that cater to firms and households.

24. Crucially, the impact of commanding own-source revenue is likely stronger for the catching-up than for the leading regions. Since poorer regions are farther away from the productivity frontier, their margin for improving policy tends to be larger, and policy improvements in turn tend to yield larger improvements in performance. In other words: lagging regions are more innovative in decentralised frameworks, and their policy innovations are more successful. Indeed some empirical evidence suggests that similar policy reforms tend to have a larger growth effect in catching-up than in leading regions (Barankay and Lockwood, 2007). The varying reaction of leading and catching-up regions to the forces of inter-jurisdictional competition - with catching-up regions reacting more vigorously to reform needs could be the main driver of convergence in decentralised settings. 
25. Finally, tax autonomy might help non-agglomerated regions to compete against the gravitational pull of agglomerations (Baldwin and Krugman, 2004). Since peripheral jurisdictions cannot provide agglomeration benefits, their only policy tool to attract and retain firms and residents is their ability to offer lower taxation and better public service levels. Fiscal and in particular tax autonomy might hence help these regions catch up.

\subsection{Trade-offs between regional activity and regional income could become apparent}

26. Some caveats need to be addressed, in particular with respect to the role of intergovernmental transfers. While transfers might slow down or even reverse convergence of sub-national output per capita, they have a key role in equalising sub-national revenues in order to ensure similar public service levels between jurisdictions (OECD 2014a, chapter 5). In other words, while transfers tend to widen differences in sub-national output, they still play an important role in reducing differences in sub-national income. In order to make all jurisdictions enjoy the benefits of more fiscal power, intergovernmental transfers and fiscal equalisation should be carefully re-designed, concomitant to the devolution of fiscal power to subcentral governments. Unfettered decentralisation could spur regional convergence but at the price of large inter-jurisdictional migration and population concentration in a few areas, an outcome often seen as politically untenable.

\section{Policy implications}

27. Fiscal decentralisation can help reverse the trend of rising disparities between sub-central governments. In particular, a policy of fostering own-source revenue - taxes, user fees and other revenue that remains in the territory where it is generated - could spur growth in poorer jurisdictions and underpin the catch-up process towards the frontier jurisdictions. Concomitantly, the size of the intergovernmental grants system should be reduced. However, grants still have a role to play as they can help reduce differences in regional income and ensure similar public service standards across the country. As such, reforms to intergovernmental frameworks aimed at lower disparities should be two-pronged:

- More own-source revenue for sub-central governments: The fiscal power of sub-central governments should be strengthened and the share of own revenue in general government revenue increased. The size of the transfer system should be reduced. On average, sub-central governments should be in a position to cover most spending with own tax and other forms of own revenue.

- A redesign of intergovernmental grants: The remaining intergovernmental transfers should be redesigned. The transfer system should be reformed so that its primary role is to reduce differences in sub-central income (fiscal equalisation), while minimising the drag on sub-central economic effort. A few grants may also help underpin sub-national activity directly (e.g. investment grants). 


\section{Bibliography}

Baldwin, R. and P. Krugmann (2004), “Agglomeration, Integration and Tax Harmonization“, NBER Working Paper, No. 9290.

Barankay, I. and Lockwood B. (2007), "Decentralization and the Productive Efficiency of Government: Evidence from Swiss Cantons”, Journal of Public Economics, No. 91.

Bénassy-Quéré, A., N. Gobalraja and A. Trannoy (2007), “Tax and Public Input Competition”, Economic Policy, April.

Bartolini, D., S. Stossberg and H. Blöchliger (2016), "Fiscal Decentralisation and Regional Disparities", OECD Economics Department Working Papers, No. 1330, OECD Publishing, Paris.

Blöchliger, H. and B. Égert (2013), "Decentralisation and Economic Growth - Part 2: The Impact on Economic Activity, Productivity and Investment”, OECD Working Papers on Fiscal Federalism, No. 15, OECD Publishing, Paris. http://dx.doi.org/10.1787/5k4559gp7pzw-en

Breton, A. (1996), Competitive Governments. An Economic Theory of Politics and Public Finance, Cambridge University Press, New York.

Ciccone, A. and R. E. Hall (1996), "Productivity and the Density of Economic Activity”, American Economic Review, 86 (1), pp. 54-70.

Ezcurra, R. and P. Pascual (2008), "Fiscal Decentralization and Regional Disparities: Evidence from Several European Union Countries, Environment and Planning A, No. 40, pp. 1185-1201.

Gil, C., P. Pascual and M. Rapun (2004), "Regional Economic Disparities and Decentralization, Urban Studies, No. 41, pp. 71-94.

Glaeser, E. L. (2000), "The New Economics of Urban and Regional Growth", in: Clark, G.L., M. P. Feldman and M. S. Gertler (eds.), The Oxford Handbook of Economic Geography, Oxford University Press, Oxford.

Garcilazo, E. and J. Oliveira Martins (2013), "The Contribution of Regions to Aggregate Growth in the OECD", OECD Regional Development Working Papers, No. 2013/28, OECD Publishing, Paris. DOI: http://dx.doi.org/10.1787/5k3tt0zzp932-en

Grossman, P. (1994), “A Political Theory of Intergovernmental Grants”, Public Choice, Vol. 78, pp. 295-303

Keen, M. and C. Kotsogiannis (2004), "Federal Tax Competition and the Welfare Consequences of Decentralization”, Journal of Urban Economics, Vol. 56, pp. 397-407. 
Kyriacou, A. P., L. Muinelo-Gallo and O. Roca-Sagalés (2015), "Fiscal Decentralization and Regional Disparities: The Importance of Good Governance", Papers in Regional Science, No. 94, pp. 89-107.

Kessler, A. and C. Lessmann (2010), "Interregional Redistribution and Regional Disparities: how Equalisation Does (not) Work", CESifo Discussion Paper, No. 8133.

Lessmann, C. (2012), “Regional Inequality and Decentralization: an Empirical Analysis”, Environment and Planning A, Vol. 44, pp. 1363-1388.

McCann, P. (2008), “Globalisation, Multinationals and the BRICS”, in: Globalisation and Emerging Economies: Brazil, Russia, India, Indonesia, China and South Africa, OECD Publishing.

Montfort, P. (2008), “Convergence of EU Regions: Measures and Evolution”, Regional Policy Working Paper, 1/2008, European Commission.

OECD (2009), How Regions Grow: Trends and Analysis, OECD Publishing, Paris.

OECD (2014a), Fiscal Federalism 2014: Making Decentralisation Work, OECD Publishing, Paris.

OECD (2014b), OECD Economic Surveys: Slovak Republic, OECD Publishing, Paris. http://dx.doi.org/10.1787/eco_surveys-svk-2014.

OECD (2015a), Taxing Wages 2015, OECD Publishing, Paris. http://dx.doi.org/10.1787/tax_wages-2015-en.

OECD (2015b), “The Future of Productivity”, Joint Economics Department and Directorate for Science, Technology and Innovation Policy Note, July 2015.

Prud’homme, R. (1995), “The Dangers of Decentralization”, World Bank Research Observer, 10, pp. 201-220.

Qian, Y. and B. Weingast (1997), “Federalism as a Commitment to Preserving Market Incentives”, Journal of Economic Perspectives, 11, pp. 83-92.

Roberts, M. and M. Setterfield (2007), “What is Endogenous Growth?”, in: P. Arestis, M. Baddeley and J. S. L. Mccombie (eds.), Understanding Economic Growth. New Directions in Theory and Policy, Edward Elgar, Cheltenham.

Rodríguez-Pose, A. and R. Ezcurra (2010), “Does Decentralization Matter for Regional Disparities? A Cross-Country Analysis”, Journal of Economic Geography, 10.

Treisman, D. (2007), The Architecture of Government. Rethinking Political Decentralization, Cambridge Studies in Comparative Politics, Cambridge UP.

Young, A., M., J. Higgins and D. Levy (2008), “Sigma Convergence versus Beta Convergence: Evidence from U.S. County-Level Data”, Journal of Money, Credit and Banking, Vol. 40, No. 5.

Zodrow, G. and P. Mieszkowski (1986), "Pigou, Tiebout, Property Taxation, and the Underprovision of Local Public Goods”, Journal of Urban Economics, Vol. 19, No. 3. 


\section{Appendix}

\section{A1. Measuring regional convergence}

28. Measuring output or income disparities and convergence is not that straightforward as it might seem at first. There are several definitions of "convergence", and no single measure can capture all aspects of differences in income and their evolution over time. It is therefore important to understand the specific benefits and limits of individual disparity or convergence measures. The most commonly used convergence measures are Beta-convergence and Sigma-convergence. The most common measures for economic activity and income are GDP (output) per capita and household income.

\section{Beta-convergence}

29. Beta-convergence refers to regional growth rates and the relationship between initial GDP levels and growth rates of a set of countries or regions as shown by the "beta-coefficient". Beta-convergence describes a process where poor regions grow faster than rich ones and are therefore catching up. Betaconvergence is measured by estimating a growth function of the following form:

$$
\ln \left(\Delta y_{i t}\right)=\alpha+\beta \ln \left(y_{i, t-1}\right)+\gamma Z_{i t}+u_{i t}
$$

where $\ln \left(\Delta y_{i t}\right)$ and $y_{i, t-1}$ are respectively the level and the growth rate of GDP per head in region $i$ at time $t ; Z_{i t}$ includes all other factors affecting the growth rate; and $u_{i t}$ is the error term. Regions are converging if the beta coefficient is significant and negative. Convergence is unconditional if all other variables are insignificant, which means that income across jurisdictions converges towards the same level. It is conditional otherwise and income differences will prevail in the long term, depending on the other growth drivers. Beta strongly depends on the choice of the other exogenous variables affecting regional growth, and spatial correlation may lead to "groups" of regions with similar growth rates but whose growth rate differs across groups.

\section{Sigma convergence}

30. Sigma-convergence refers to a reduction of disparities - or differences in GDP per capita among regions over time. The most common measure for assessing sigma convergence is the coefficient of variation, or standard deviation of regional GDP per capita divided by average (national) GDP per capita, and is estimated in the following way:

$$
\operatorname{COV}_{i t}=\alpha+\delta\left(\operatorname{COV}_{i, t-1}\right)+\gamma Z_{i t}+u_{i t}
$$

where COV is the coefficient of variation of regional GDP per capita, and $Z_{i t}$ includes the same factors as those affecting regional growth above. Disparities are decreasing if $\delta$ is negative, positive otherwise. Betaconvergence is necessary but not sufficient for sigma-convergence since regions may converge over time but still remain apart because of asymmetric shocks, or one region may actually grow so fast that it overtakes other regions, thereby increasing disparity. Sigma-convergence is more intuitive since it 
measures directly how equal or unequal jurisdictions become over time, rather than measuring the growth process. Also, sigma convergence tends to be less sensitive to the use of a particular growth model.

31. This is why this paper focuses on sigma-convergence. The analysis of coefficients of variation, capturing the overall distribution of regional GDP per capita, is supplemented by extreme value analysis, answering questions such as how leading or lagging regions have evolved relative to the average or relative to each other and under which policy settings.

\section{A2. Summary of the empirical approach}

32. The following reduced-form specification underlies the relationship between decentralisation and differences in regional output (for details see Bartolini et al., 2016):

$$
\operatorname{COV}_{i t}=\mathrm{c}+\beta_{1} D E C_{i t}+\beta_{2} Z_{i t}+\beta_{3} T_{i t}+u_{i}+v_{t}+\varepsilon_{i t}
$$

The dependent variable $\mathrm{COV}_{i t}$ is the annual coefficient of variation of output-based regional GDP per capita in country $i$ and year $t$. The indicator $D E C_{i t}$ measures decentralisation in country $\mathrm{i}$ and year $\mathrm{t}$ as measured, alternatively: by the share of sub-central to total government spending; sub-central to total government revenue; sub-central to total tax revenue; tax autonomy; and regional autonomy. For some estimations, specific decentralisation variables (e.g. decentralisation of education or social welfare or the decentralisation of the income tax) are used. The vector of the $\mathrm{Z}$ variables includes trade, human capital (approximated by years of schooling) and working age population. The territorial variables $\mathrm{T}$ include population density and the degree of urbanisation, often thought to be associated with larger disparities. $u_{i}$ and $v_{t}$ are country-fixed and time-fixed effects, respectively.

33. Several independent variables are interacted with the decentralisation variables (government size, urbanisation, population density). Several alternative specifications (FE, TSLS, time fixed effects to allow for a common decentralisation trend) are tested. In order to assess the disparity-reducing effect in detail, a set of regressions is run to test how the ratio of the richest $10 \%$ or $25 \%$ regions to the poorest $10 \%$ or $25 \%$ regions evolves when countries are decentralising. 